Dokuz Eylül Üniversitesi-Mühendislik Fakültesi

Fen ve Mühendislik Dergisi

Cilt 20, Sayı 60, Eylül, 2018
Dokuz Eylul University-Faculty of Engineering Journal of Science and Engineering Volume 20, Issue 60, September, 2018

DOI: 10. : 10.21205/deufmd. 2018206057

\title{
Factors Effecting the Shear Strength of Geotextile Reinforced Compacted Clays
}

\section{Eyyüb KARAKAN*1,}

${ }^{1}$ Kilis 7 Aralık Üniversitesi, Mühendislik Mimarlık Fakültesi, İnşaat Mühendisliği Bölümü, 79000, Kilis (ORCID: 0000-0003-2133-6796)

(Alınış / Received: 07.09.2017 Kabul / Accepted: 13.04.2018, Online Yayınlanma / Published Online: 15.09.2018)

Keywords Geosynthetics, reinforced clay, unconfined compression test, stress strain relationship.

\begin{abstract}
In this study, it was aimed to investigate the potential advantages of the use of geotextiles as a reinforcing material, and an evaluation of their effects on mechanical behavior of clayey soils was made, including a comparison of the experimental results obtained with those from earlier studies concentrated on the same topic. As a result, a series of unconfined compression tests were conducted to evaluate certain parameters which possibly influences the behavior of geotextile reinforced clayey soil. For this aim, parameters including geotextile type (nonwoven, woven), water content, rate of loading and the number of geotextile layers were analyzed .
\end{abstract}

\section{Geotekstil Donatılı Kil Zeminlerin Kayma Dayanımına Etki Eden Faktörler}

\begin{abstract}
Anahtar Kelimeler Özet: Bu çalışmada donatılı zemin olarak geotekstil kullanımının potansiyel avantajlarının araştırılması amaçlanmış ve kil

Geosentetik, Kil Zemin, Serbest Basınç Deneyi,

Gerilme Şekil

Değiştirme İlişkisi zeminlerin mekanik davranıșına olan etkileri hesaplanmıștır. Elde edilen deneysel sonuçlar ile aynı konuda daha önceki çalışmaların karşılaştırması yapılmıştır. Sonuç olarak, geotekstille güçlendirilmiş kil zeminin davranışını etkileyebilecek bazı parametreler tanımlanmış ve bir dizi serbest basınç deneyi gerçekleştirilmiştir. Bu amaçla, incelenen parametreler, geotekstil türü (örgülü, örgüsüz), su içeriği, yükleme hızı ve kullanılan geotekstil katmanlarının sayısını içermektedir.
\end{abstract}

\footnotetext{
*Sorumlu yazar: eyyubkarakan@kilis.edu.tr
}

\section{Introduction}

Soil reinforcement is a viable method which provides improvement in engineering properties of soils. Traditional geosynthetics, such as geotextile is proved to be efficient, and increasingly used in geotechnical engineering practice [1]. Geotextiles are used as reinforcing elements in many civil engineering applications. Many experimental studies were performed on granular soils, while studies on cohesive soils were fewer. Mechanical properties of reinforced clayey soil, especially shear 
strength, is of utmost most importance in practical applications.

As mentioned above, studies concerning geotextile reinforced cohesive soils are limited. Ingold [2] and Ingold and Miller [3], performed a series of undrained triaxial tests to study the behavior of a reinforced highly plastic clay. They reported the results of undrained triaxial tests on a kaolin type clay reinforced by aluminum plates. In study of Lafleur et al. [4] non woven and woven geotextiles were used to investigate the effect of reinforcement on mechanical behavior of cohesive soils by direct shear tests. Consolidated undrained and consolidated drained triaxial tests were performed to investigate the behavior of clay reinforced with geomesh by $\mathrm{Al}$ Omari et al.), [5]. Additionally, Indraratna et al.)[6] used the non-woven and woven geotextiles to investigate the mechanical properties of reinforced with silt clay mixtures. Experimental and analytical studies were carried out to assess the behavior of reinforced cohesive soil by Zornberg and Mitchell , [7]. Unnikrishnan et al. , [8]questioned the effect of sand layer thickness, moisture content and reinforcement types. Noorzad and Mirmoradi , [9] conducted a study to evaluate the behavior of cohesive soil reinforced with a geotextile, from unconfined and unconsolidatedundrained (UU) triaxial compression tests.

Ghazavi and Roustaie, [10] investigated the effect of freeze-thaw cycles on the compressive strength of fiber-reinforced clay. They used kaolinite clay reinforced by steel and polypropylene fibers. The results of the study show that for the soil investigated, the increase in the number of freeze-thaw cycles results in the decrease of unconfined compressive strength of clay samples by $20-25 \%$.
Many investigators have used fiber to improve various properties of sandy soil (e.g., Maher and Gray [11]; Al-Rafeai [12]; Consoli et al. [13]; Yetimoglu and Salbas [14] ; Ahmad et al. [15]). These investigations revealed that the strength of reinforced soil is increased with increasing fiber content, aspect ratio and friction between soil and fiber.

Although majority of the published literature on randomly oriented fiber reinforced soils are focused on reinforced cohesionless or granular soils, results from a limited number of studies emphasized that cohesive soils can also be reinforced and such reinforced soils can be beneficial in practice (e.g., Maher and Ho 1994 [16]; Consoli et al. 2002[17]; Mesbah et al. 2004 [18]; Kumar et al. 2006 [19]; Tang et al. 2007 [20] and Attom et al. 2009[21]).

This study aims to investigate the characteristics of $q_{u}$, (unconfined compressive strength) $\varepsilon_{\mathrm{f}}$, (axial strain at failure) and $E_{50}$ (modulus of elasticity) of a geotextile reinforced clay. A series of unconfined compression tests (UCT) were carried out to evaluate the strength and stress-strain properties. The effects of geotextile layer, geotextile type, loading rate, water content on $\mathrm{q}_{\mathrm{u}}, \varepsilon_{\mathrm{f}}$, and $\mathrm{E}_{50}$ are investigated.

\section{Materials and Experimental Program}

In this study, 234 unconfined compression tests were performed to investigate the effects of varying soil parameters on the mechanical behavior of unreinforced and reinforced cohesive soils. The samples were compacted by application of standard Proctor effort. The experiments were carried out on specimens with a diameter of $50 \mathrm{~mm}$ and a height of $100 \mathrm{~mm}$. Two types of nonwoven geotextiles and two types of woven geotextiles were used. The 
physical and mechanical properties of these geotextiles are provided in Table 1. Clay is obtained from the city center of Balikesir in Turkey. The clay was classified as low plasticity clay (CL) according to the Unified Soil Classification System. The particle size of clay was determined according to the ASTM D 422-63 [22].

The soil properties is shown in Table 2 . All the soil properties were determined by testing as per relevant ASTM standards. Ingold and Miller [3] explained how to constitute a geotextile reinforced sample for testing. Preparation of clay sample is important for laboratory studies. Firstly, the water content of the clay was determined. Then clay was mixed with water and placed within desiccator and sealed for 48 hours to obtain uniform water content. Moisture content was checked after the clay has been sealed. Insignificant changes in water contents were recorded. Samples were prepared in a mold of diameter $50 \mathrm{~mm}$ and a height $100 \mathrm{~mm}$. In sample were preparation, equal number of layers were used and a static compaction method was applied to the soil layers.

Four different geotextile types are used in this study as shown in Figure 1. In addition to the routine experimental program, some randomly selected test cases are re-applied to check the validation of sample preparation and same loading conditions and to verify the repeatability and the accuracy of the results (Figure 2). A series of tests were performed on unreinforced and reinforced samples. The rate of loading was kept at a constant rate of $5 \mathrm{~mm} / \mathrm{min}$. The average axial stress on unreinforced samples was nearly $180 \mathrm{kPa}$, corresponding to an average axial strain of $5.4 \%$. The experiments were conducted on specimens at six different moisture contents: $2 \%$ and $4 \%$ percent below the optimum moisture contents, optimum moisture content and $2 \%, 3 \%$, $4 \%$ above the optimum moisture contents. Three different loading rates were selected $(0.1 \mathrm{~mm} / \mathrm{min}, 1 \mathrm{~mm} / \mathrm{min}$, $5 \mathrm{~mm} / \mathrm{min}$ ) to investigate the loading rate effects. During loading, continuous records were obtained for the axial load $(F)$, axial strain $(\varepsilon)$, and the axial stress $(\sigma)$ applied to the specimen. The specimens were prepared using the standard proctor effort and subsequently tested according to ASTM D2166 [10].

\section{Evaluation of Test Results and Discussions}

Typical test results obtained from an unreinforced clay sample in unconfined compressive testing with a loading rate of $1 \mathrm{~mm} / \mathrm{min}$. are illustrated in Figure 3 . Figure $3 \mathrm{a}$ shows the variation of the corresponding axial stress versus axial strain. When vertical load is applied incrementally, the axial strain is also increased. The variation of shear stress $(\tau)$ with axial stress $(\sigma)$ is shown in Figure $3 \mathrm{~b}$. The undrained shear strength is half of the unconfined compression strength as shown in Figure $3 \mathrm{~b}$.

The calculated values of $\mathrm{I}_{\mathrm{B}}$ and $\mathrm{E}_{50}$ are summarized in Table 3. The definition of $\mathrm{E}_{50}$ is , as expressed below:

$$
E_{50}=\frac{2 * \sigma_{1 / 2}}{\varepsilon_{\mathrm{f}}}
$$

where, $\sigma_{1 / 2}=$ stress corresponding to half of the strain at failure obtained from the Unconfined Compression Test (UCT). The strength ratio, $\mathrm{S}$ can be defined as the axial stress to unreinforced axial stress.

$$
\mathrm{S}=\frac{\sigma_{\text {reinforced }}}{\sigma_{\text {unreinforced }}}
$$

Likewise, dimensionless inverse aspect ratio, $\rho$, can be defined as the diameter of the sample, $d$, is divided by the height, $h$, of clay between consecutive reinforcing 
layers. Another parameter is the brittleness index, $\mathrm{I}_{\mathrm{B}}$, in which;

$\mathrm{I}_{\mathrm{B}}=\frac{\text { Peak Strength }- \text { Residual Strength }}{\text { Peak Strength }}$

It is also shown that the brittleness index decreased with increasing number of geotextile layer. The secant modulus decreased with increasing number of geotextile layers as shown in Table 3.

\subsection{Effect of Number of Geotextile} Layers on the Stress Strain Properties

Axial stresses are plotted versus axial strain for the results of unconfined compression tests performed on unreinforced and reinforced the samples which were compacted at optimum water content of (Figure 4). In this part, all the tests are examined on G1 type (non woven) geotextile. The curves in Figure 4 were achieved for optimum water content $\left(\omega_{\text {opt }}=24.5 \%\right)$ under constant loading rates of $1 \mathrm{~mm} / \mathrm{min}$. Similar curves were achieved for the 0.1 $\mathrm{mm} / \mathrm{min}$. and $5 \mathrm{~mm} / \mathrm{min}$. loading rates that show the variation of the axial stress versus the axial strain for the samples prepared at their optimum water contents. The curves in Figure 4 are for four types of geotextile layers.

The number of geotextile layers has greater influences on stress-strain curves, in comparison with the effect of loading rates. The stress strain curves of these samples are quite similar and significance of loading rate is relatively low, in comparison with other parameters (Figure 4). The curves provide evidence of an improvement in the mechanical properties of clay with the addition of the geotextile. Stress strain behavior of soil improved with an increase in the number of geotextile layers. For example, sample including four layers of geotextile is failed under $250 \mathrm{kPa}$ axial stress, however, unreinforced sample has $145 \mathrm{kPa}$ axial stress. Similar results were also reported by Ingold ,[2] and Ingold and Miller [3],Indraratna et al., [6]. Another explanation for such behavior could be that the geotextile layers intercept the failure plane within the specimen, distributing the stresses evenly within the soil and hence, inceasing the overall strength of the reinforced soil (Figure 4).

As illustrated in Figure 4, the reinforced samples failed under higher axial stresses in comparison with the unreinforced soil, and as the number of geotextiles further increases the axial stress increases.

\subsection{Effect of Loading rate on the Stress Strain Properties}

The effect of loading rate is illustrated in Figure 5. All the comparisons are made by use of single layer on reinforced soils, which was compacted at optimum moisture content. As illustrated in Figure 5 , the $5 \mathrm{~mm} / \mathrm{min}$. loading rate have higher peak strength in comparison to that of $0.1 \mathrm{~mm} / \mathrm{min}$. loading rate. The 0.1 $\mathrm{mm} / \mathrm{min}$. loading rate figured out the minimum axial stress. When the loading rate increased 10 times, the axial stress increased only 0.1 times. Therefore, the loading rate does not have a great influence on sample strength. In addition, it is also seen clearly that four different geoxtile types gives the similar results as shown in Figure 5. These outcomes are in agreement with the findings of Noorzad \& Mirmoradi (2010),[12]. 
E. Karakan. / Mechanical Behavior of Clay Soils Reinforced with Geosynthetics

Table 1. Types of geotextile used in the present study (provided from the suppliers technical brochures)

\begin{tabular}{|c|c|c|c|c|c|c|c|}
\hline \multirow[t]{2}{*}{$\begin{array}{l}\text { Geotextile } \\
\text { label }\end{array}$} & \multirow[t]{2}{*}{$\begin{array}{l}\text { Geotextile } \\
\text { type }\end{array}$} & \multirow{2}{*}{$\begin{array}{c}\text { Nominal } \\
\text { mass per } \\
\text { unit area } \\
\left(\mathrm{g} / \mathrm{m}^{2}\right)\end{array}$} & \multirow[t]{2}{*}{$\begin{array}{l}\text { Thickness } \\
\text { (mm) }\end{array}$} & \multirow{2}{*}{$\begin{array}{c}\text { Tensile } \\
\text { strength } \\
(\mathrm{kN} / \mathrm{m})\end{array}$} & \multicolumn{2}{|c|}{$\begin{array}{c}\text { Elongation at } \\
\text { failure (\%) }\end{array}$} & \multirow{2}{*}{$\begin{array}{l}\text { Opening } \\
\text { size }(\mathrm{mm})\end{array}$} \\
\hline & & & & & height & width & \\
\hline $\begin{array}{c}\text { Izoteknik } \\
1000-\mathrm{G} 1\end{array}$ & $\begin{array}{c}\text { Non- } \\
\text { woven }\end{array}$ & 100 & 1 & 2.5 & 80 & 80 & 0.17 \\
\hline $\begin{array}{l}\text { Izoteknik } \\
2500-\mathrm{G} 2\end{array}$ & $\begin{array}{c}\text { Non- } \\
\text { woven }\end{array}$ & 250 & 2.50 & 8 & 50 & 80 & -- \\
\hline $\begin{array}{c}\text { SUNJUT / } \\
\text { PP/80/80- } \\
\text { G3 }\end{array}$ & Woven & & & 80 & 19 & 15 & 0.12 \\
\hline $\begin{array}{c}\text { SUNJUT / } \\
\text { PP/60/60- } \\
\text { G4 }\end{array}$ & Woven & & & 60 & 17 & 13 & 0.18 \\
\hline
\end{tabular}

Table 2: Properties of clay used in experiments.

\begin{tabular}{|l|c|}
\hline Unified soil classification system (USCS) & CL \\
\hline Passing percent No. 200 sieve, \% & 90 \\
\hline Liquid limit, $\mathrm{w}_{\mathrm{L}}(\%)$ & 48 \\
\hline Plastic limit, $\mathrm{wP}_{\mathrm{P}}(\%)$ & 27.50 \\
\hline Plasticity index, $\mathrm{I}_{\mathrm{p}}(\%)$ & 20.50 \\
\hline Specific gravity of solids, Gs & 2.63 \\
\hline Maximum dry unit weight, $\rho_{\mathrm{d}}\left(\mathrm{Mg} / \mathrm{m}^{3}\right)$ & 14.50 \\
\hline Optimum moisture content, $\mathrm{w}_{\text {opt }}(\%)$ & 24.50 \\
\hline
\end{tabular}

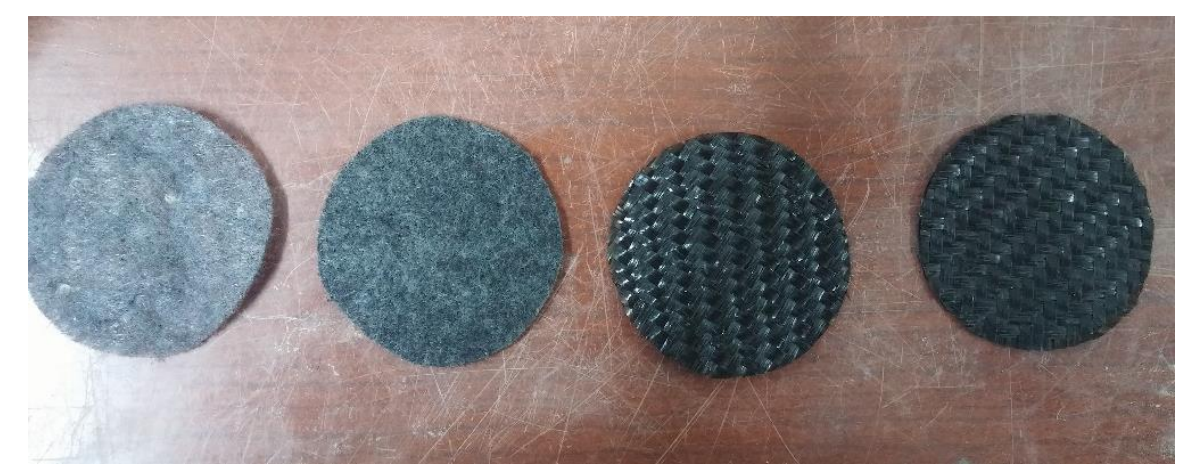

Figure 1. Different types of geotextiles used in the experiments (from left to right: the nonwoven geotextiles G1, G2; the woven geotextiles, G3 and G4) 
E. Karakan. / Mechanical Behavior of Clay Soils Reinforced with Geosynthetics

Table 3: The brittleness index and Secant Modulus

\begin{tabular}{|c|c|c|c|c|c|c|}
\hline $\begin{array}{c}\text { Test } \\
\text { No }\end{array}$ & Geotekstil Type & $\begin{array}{c}\text { Water } \\
\text { Content (\%) }\end{array}$ & $\begin{array}{c}\text { Loading Rate } \\
(\mathrm{mm} / \mathrm{min} .)\end{array}$ & $\begin{array}{c}\text { Geotextile } \\
\text { Layers }\end{array}$ & $\mathrm{I}_{\mathrm{b}}$ & $\mathrm{E} 50(\mathrm{kPa})$ \\
\hline 1 & Unreinforced & 24.5 & 0.1 & 0 & 0.807 & 5697.20 \\
\hline 2 & $\mathrm{G} 1$ & 24.5 & 0.1 & 1 & 0.435 & 3543.93 \\
\hline 3 & $\mathrm{G} 1$ & 24.5 & 0.1 & 2 & 0.398 & 2929.16 \\
\hline 4 & $\mathrm{G} 1$ & 24.5 & 0.1 & 3 & 0.206 & 2884.43 \\
\hline 5 & $\mathrm{G} 1$ & 24.5 & 0.1 & 4 & 0.093 & 2732.71 \\
\hline
\end{tabular}

\subsection{Effect of Geotextile Types on the Stress Strain Relationship}

The stress-strain curves in Figure 6 were evaluated for one and two layers of geotextile reinforcement and under constant loading rate of $1 \mathrm{~mm} / \mathrm{min}$. The peak stress values for four types of geotextile follows order of G2, G4, G1 and G3. From Figure 6, clay reinforced with G2 type geotextile (non woven) is failed under highest axial stress: since nonwoven geotextiles (G1, G2) have the higher thickness. As shown in Figure 6 the woven geotextiles (G3, G4) with reinforced clay gets the lowest axial stress. It is also shown that the nonwoven geotextiles (G1, G2) have a greater influence on the strength parameters. It can be said that non woven geotextiles provide more strength and flexibility for reinforced samples than woven geotextiles (Figure
6). The stiffnesses of reinforced specimens were found to be lower than that of the unreinforced specimen. This fact is more clearly seen when the number of geotextile layers increased. This behavior may be justified by the load elongation curve of the geotextile, which is readily provided by the manufacturer (Table 1). The load elongation curves of the two types (nonwoven- woven) of geotextile used in the present study were different, as the failure strains for the nonwoven and woven type geotextiles were reported as 80 and 15 percent, respectively by the manufacturer. This is why it is observed in Figure 6 that the stiffness of the samples reinforced with the nonwoven and woven type geotextile is dissimilar. 


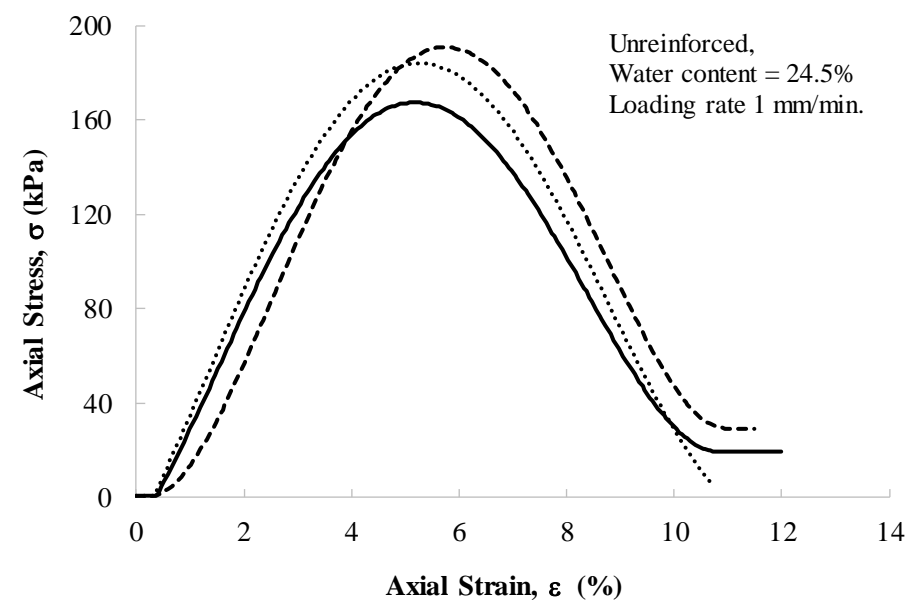

Figure 2. Repeatability of test results
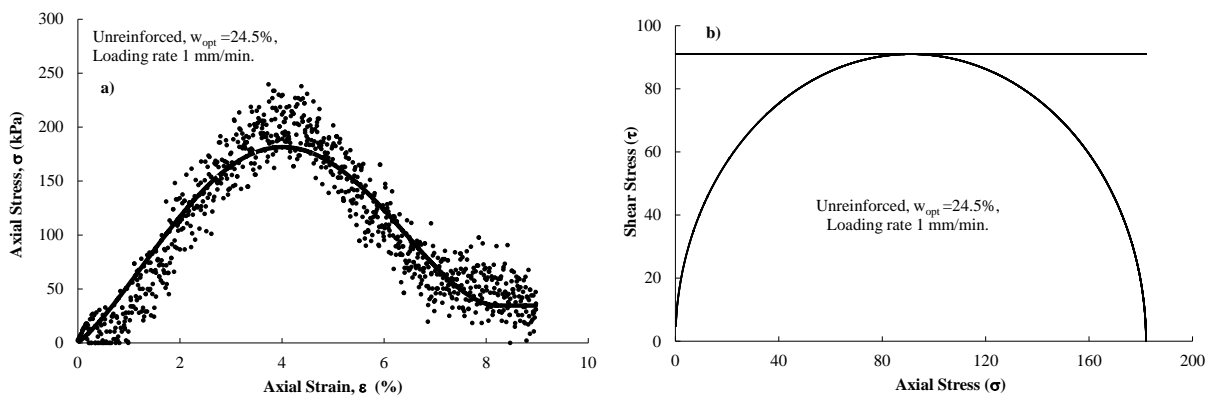

Figure 3. a) Typical stress strain curves for an unconfined compression test for clay b) MohrCoulomb plot for an unconfined compression test for clay

\subsection{Effect of Water Content on the Stress Strain Relationship}

In this study, to illustrate the conditions in the field five different water contents are considered, 2 and $4 \%$ above optimum water content, optimum water content and $2 \%$ and $4 \%$ below water content. Shear strength of soils vary also depending on the water content of compaction. In this case, the effect of change in water content on the stressstrain behavior of reinforced soils were tried to be determined experimentally. The stress strain curves for reinforced samples with one layer of geotextile are shown in Figure 7.

As can be seen in Figure 7, axial deformations at failure are lower for the specimens prepared at the wet of optimum than for the other specimens. On the contrary, axial deformations at failure are recorded to be relatively higher. Greatest strength is observed by testing specimens at their optimum moisture content. 


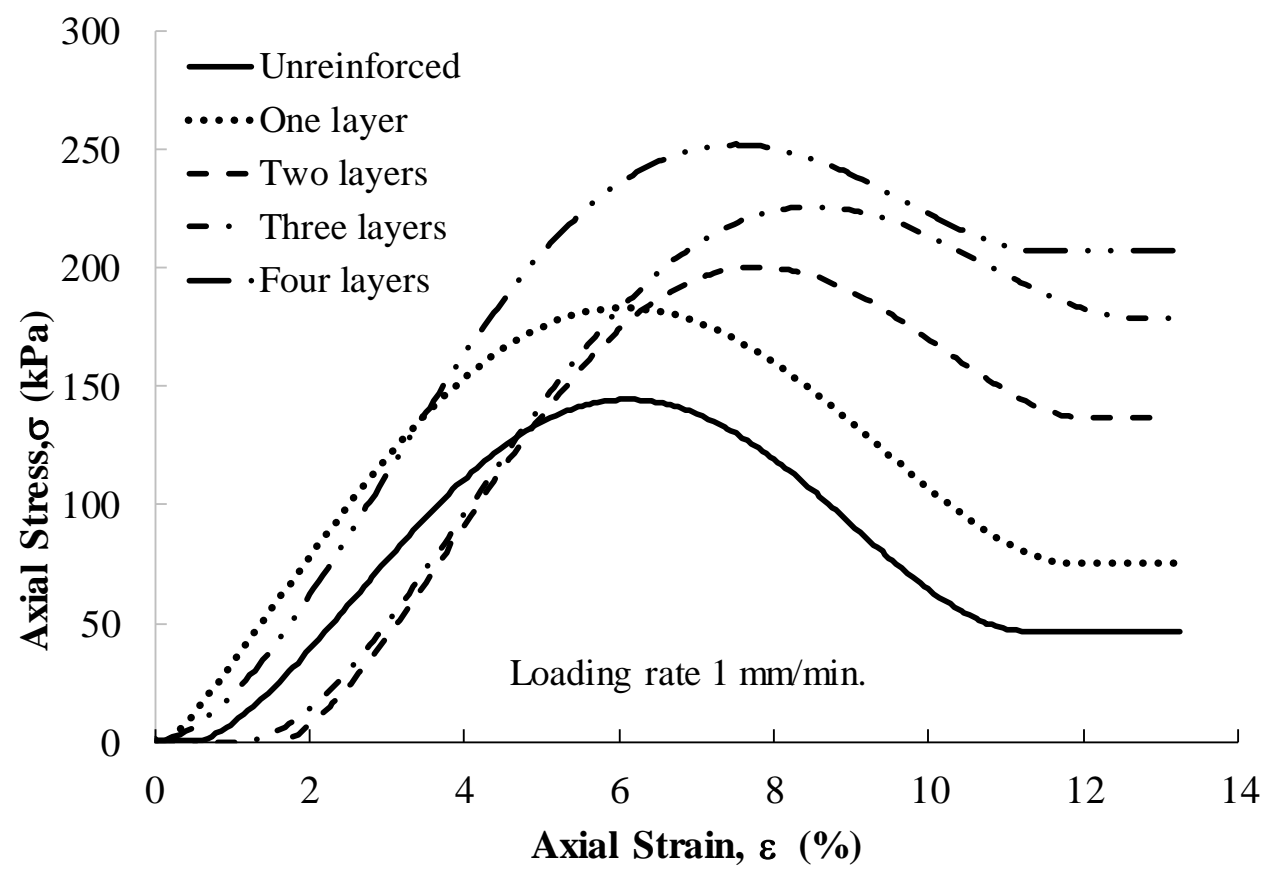

Figure 4: Stress-strain curves for unreinforced and reinforced clay with several layers of G1 type geotextile for the water content $\left(\mathrm{w}_{\mathrm{opt}}=24.5 \%\right)$.
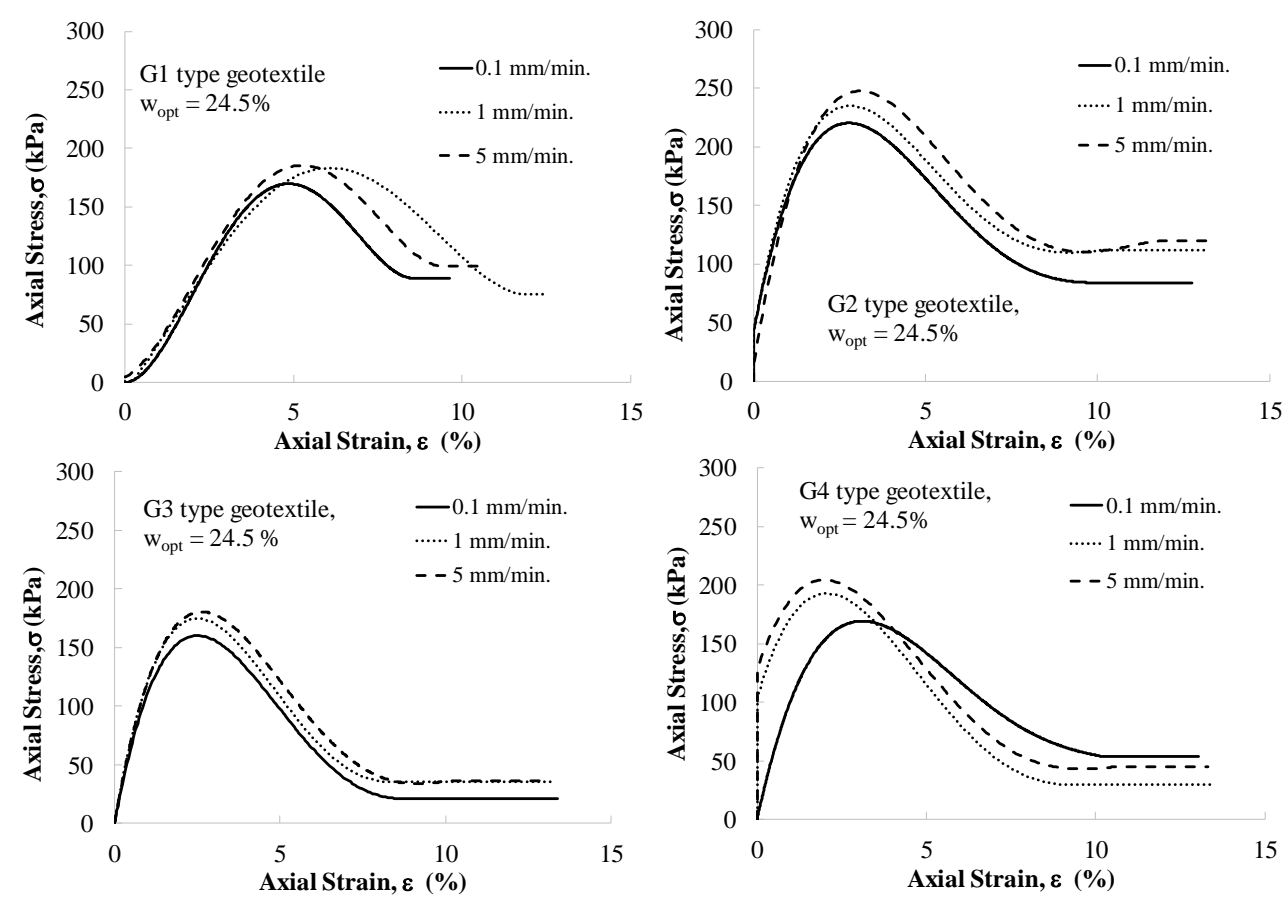

Figure 5. The effect of loading rate on stress-strain relationships for reinforced clay with one layer of geotextile (specimens are prepared at $\mathrm{w}_{\mathrm{opt}}=24.5 \%$ ). 

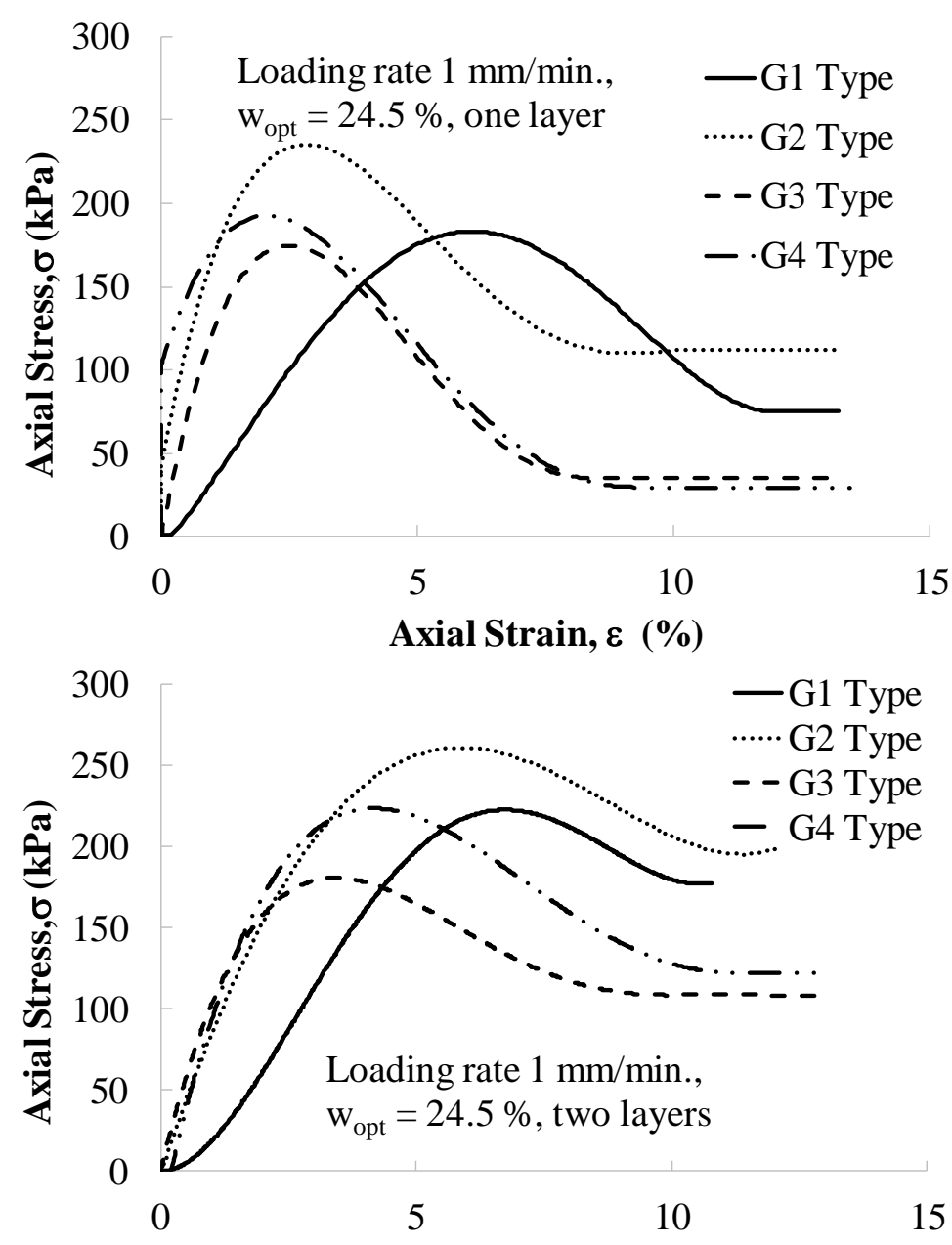

Axial Strain, $\varepsilon(\%)$

Figure 6. The effect of geotextile type (G1-G2-G3-G4) on stress - strain curves for reinforced clay with one and two layers of geotextile for a moisture content of $\mathrm{w}_{\mathrm{opt}}=24.5 \%$. 


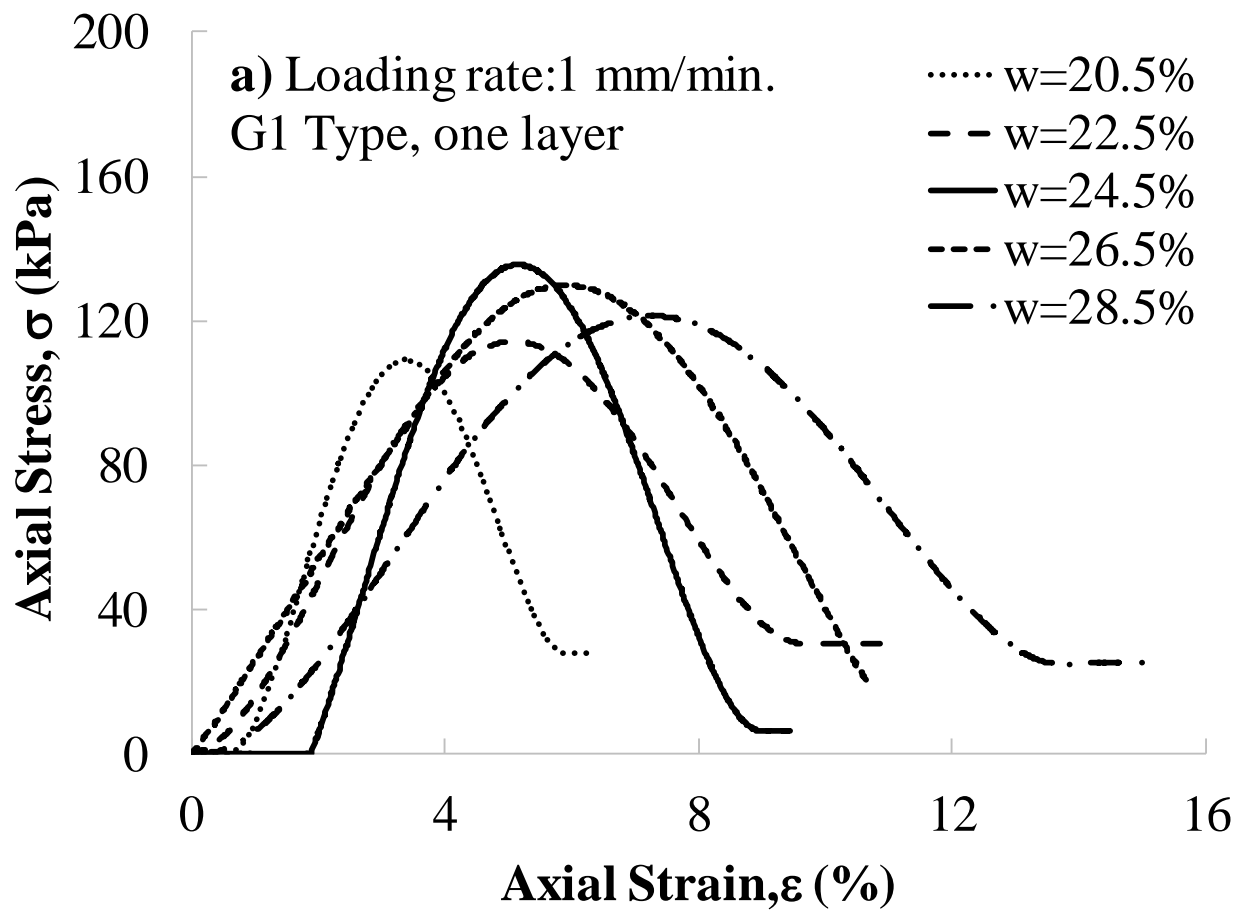

Figure 7. The effect of moisture content $\left(w_{o p t}-4, w_{o p t}-2, w_{o p t}, w_{o p t}+2, w_{o p t}+4\right)$, stress - strain curves for reinforced clay with one layer of geotextile (G1) for the constant loading rate.

\subsection{Effect of Residual Strength on the Stress Strain Relationship}

Former studies show that the number of geotextile layers is one of the most important parameter affecting the residual shear strength of reinforced soils [12]. This behavior is clearly seen in the stress strain behavior of geotextile-reinforced clay.

The stress strain relationships of unreinforced specimens were compared with those of one or two layers of reinforcement. Unconfined compression test results including residual strength behavior were obtained, as shown in Figure 8. It should be emphasized that, similar stress-strain relationships were obtained for specimens tested under 0.1 $\mathrm{mm} / \mathrm{min}$. and $5 \mathrm{~mm} / \mathrm{min}$. loading rates. As a result, the reinforced samples have higher residual strength in comparison to the unreinforced soils, and as the number of geotextiles increases, the residual strength increases further
(Figure 8). While a residual strength of $200 \mathrm{kPa}$ is obtained for clay reinforced with two layers of geotextile, a $40 \mathrm{kPa}$ residual axial stress is recorded by testing unreinforced specimen. The results clearly show that as the number of geotextile layers was increased, residual stress also increased.

\subsection{Maximum Stress Strain-Water Content Relationship}

The effect of water content on stressstrain behavior of geotextile reinforced clay is shown in Figures 9 and 10. It was observed that when the water content increases, the maximum axial stress decreases and axial stress at failure also increases. This approach can be explained by the structure of the clayey soils. When compacted soils are analyzed at the microstructural level, soil is in the form of flocculated structure onthe dry side of the optimum water content. The structural arrangement on the wet side of 
optimum water content is dispersed. Specimens compacted on the dry side of the optimum are more rigid and stronger than those compacted at the wet of optimum. This difference is seen clearly in the results of present study.

As can be seen in Figure 10, there is a bare increase in axial deformation at failure with increasing water content. In tests performed on specimens constituted using G1 type soils, greatest axial deformation at failure was observed in specimens including two geotextile layers. Although unreinforced specimens demonstrated a more brittle behavior, increase in the number of geotextile layers caused a more ductile behavior. Regardless of water content, greatest axial deformation at failure was observed by testing specimens constituted using two geotextile layers.

\subsection{Unconfined Compressive Strength - Water Content Relationship}

It can be seen from Figure 11 that $q_{u}$ increases with increasing the number of geotextile layers. The effect of water content on the behavior of the reinforced clay is also considered with reference to unconfined compressive strength. The increase in the unconfined compressive strength also indicates that the reinforcement effect on the dry side of the optimum water content is less than that of wet side. However, the difference in the unconfined compression strength between the dry and wet side of the optimum water contents is more significant with more geotextile layers. Increasing number of geotextile layers cause an increase in $\mathrm{q}_{\mathrm{u}}$, regardless of the water contents.

Figure 12 presents the relationship between unconfined compressive strength $\left(q_{u}\right)$ and number of layers $(N)$ of the soils prepared with G1 type geotextile and optimum water content. It can be seen that most values of $q_{u}$ obtained from this study fall in the range of 144 to $228 \mathrm{kPa}$, and $\mathrm{qu}_{\mathrm{u}}$ increases with increasing number of layers. With the use of regression analysis, the relationship between qu and $\mathrm{N}$ of the soils obtained from this study is well presented by a linear correlation expressed by:

$$
\mathrm{q}_{\mathrm{u}}=13.92 * \mathrm{~N}+166.69
$$

A fairly acceptable correlation coefficient, $\mathrm{R}, \quad\left(\mathrm{R}^{2}=0.82\right)$ suggests that the derived linear correlation can be used as a useful engineering tool to characterize the relation between $\mathrm{q}_{\mathrm{u}}$ and $\mathrm{N}$ of the geotextile reinforced clay soils.

\subsection{Relationship between $q_{u}$,res and Number of Layers (N)}

Figure 13 presents the relationship between residual strength and number of layers of the soils prepared with G1 type geotextile and compacted at optimum water content. It can be seen that most values of residual strength obtained from this study are within the range of 20 to $225 \mathrm{kPa}$, and residual strength increases with increasing number of layers. By using regression analysis, the relationship between residual strength ( $\mathrm{q}_{\mathrm{u}, \mathrm{res}}$ ) and number of layers $(\mathrm{N})$ of the soils obtained from this study is well presented by a linear correlation expressed by:

$\mathrm{q}_{\text {ures }}=38.60 * \mathrm{~N}+45.45$

A relatively high correlation coefficient, $\mathrm{R},\left(\mathrm{R}^{2}=0.905\right)$ suggests that the derived linear correlation can be used as a useful engineering tool to characterize the relationship between $\mathrm{q}_{\mathrm{u} \text {,res }}$ and $\mathrm{N}$ of the geotextile reinforced clay soils. The influence of residual strength changes on sample behavior is also assessed. As the number of geotextile 
layers increases, the residual strength of the reinforced sample also increases. The interesting point here is that when the water content increases, the residual strength does not increase. This means that the sample with higher water content does not have higher residual strength than the sample with lower water contents.

Figure 14 presents the relationship between strain at failure and unconfined compressive strength of unreinforced, G1, G2, G3, G4 samples with water contents of 20.5, 22.5, 24.5, 26.5 , and $28.5 \%$. It is obviously seen that highest values of $\varepsilon$ obtained from this study are scattered from 2 to $12 \%$ and $\varepsilon_{\mathrm{f}}$ decreases with increasing qu. The relationship between $\varepsilon f$ and $q_{u}$ by equation 6;

$$
\varepsilon_{\mathrm{f}}=65.97 * \mathrm{q}_{\mathrm{u}}^{-0.447}
$$

The variation of strength ratio with water content for G1 type geotextile for different numbers of geotextile layers is illustrated in Figure 15. The water content increases, strength ratio also increases indicating the reinforcement effect of geotextiles on dry side of the optimum water content is less than the higher water contents. This result is also agreement with the Fabian \& Fourie (1986), [13]; Noozard \& Mirmoradi (2010)[12]. The maximum strength ratio is obtained at $28.5 \%$ water content. The two layers of geotextile reinforced clay have greater strength ratio.

\section{Conclusions}

A series of unconfined compression tests were performed to investigate the development of stress-strain, strain at failure and residual strength-water content relations with reference to effects of loading rate, geotextile type and number of reinforcement layers. The effect of number of geotextile layers is more pronounced than that of the loading rate change. The results reveal that the number of geotextile layers have significant influence on unconfined compressive strength and strain at failure of the soils. Reinforcing improves the mechanical properties of soil, the reinforcing increases the peak strength. Increase in water content decreases the unconfined compressive strength in both reinforced and unreinforced soil specimens, soil specimens with nonwoven geotextile reinforcement show a ductile behavior when compared to unreinforced soil specimens. A simplified empirical equation was proposed for predicting the strength of the reinforced soils. The predicted values were in good agreement with the measured ones showing the accuracy of the method. 
E. Karakan. / Mechanical Behavior of Clay Soils Reinforced with Geosynthetics

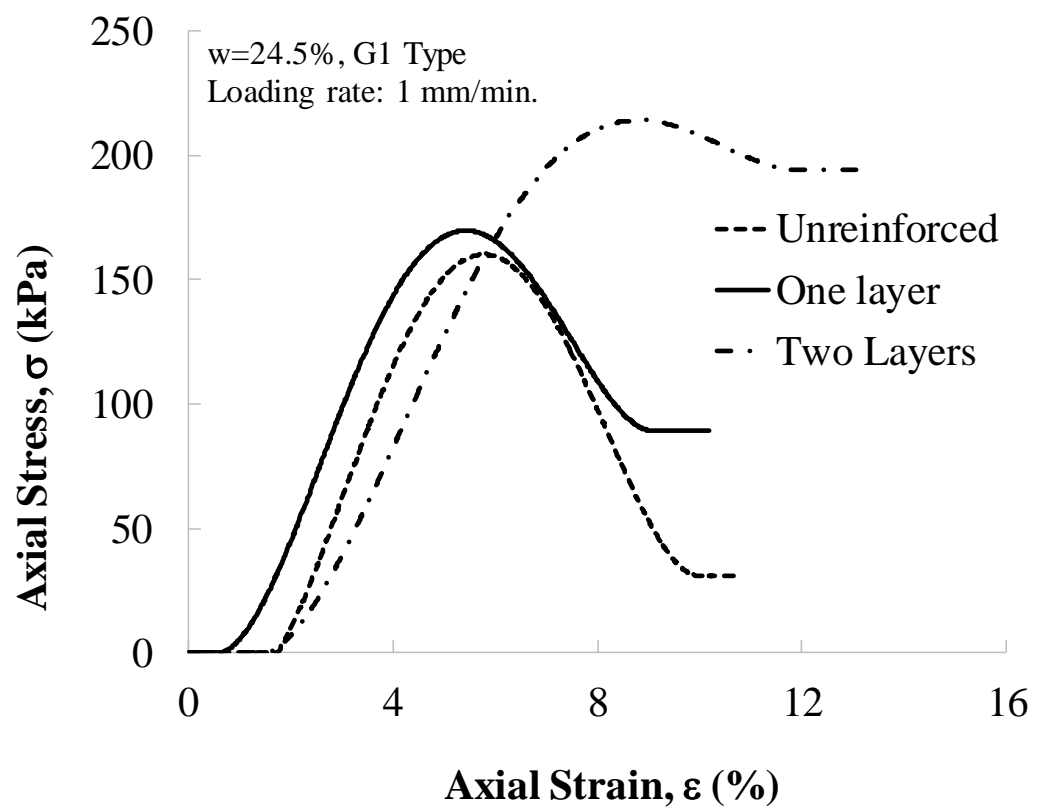

Figure 8. Stress - strain relationships for unreinforced clay and reinforced clay with single and two layers of geotextile (G1).

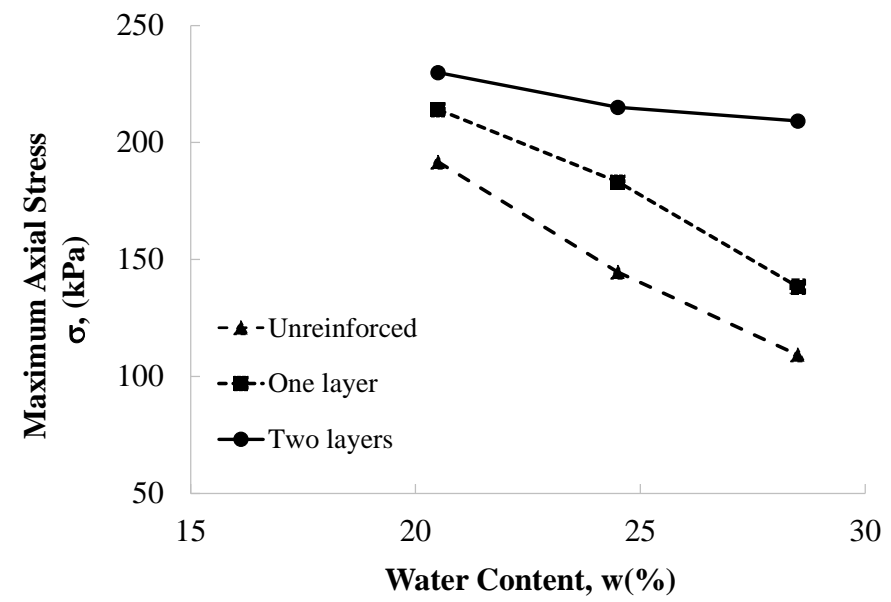

Figure 9: Variations of maximum axial stress with water content for G1 geotextile by considering effect of number of geotextile layers. 


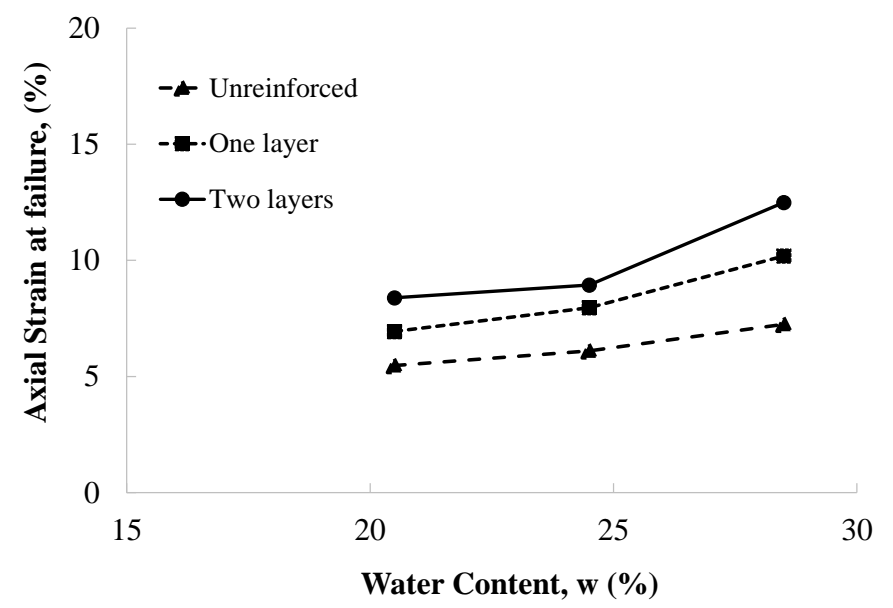

Figure 10. Variation of axial strain at failure based on water content for G1 type geotextile for different numbers of geotextile layers.

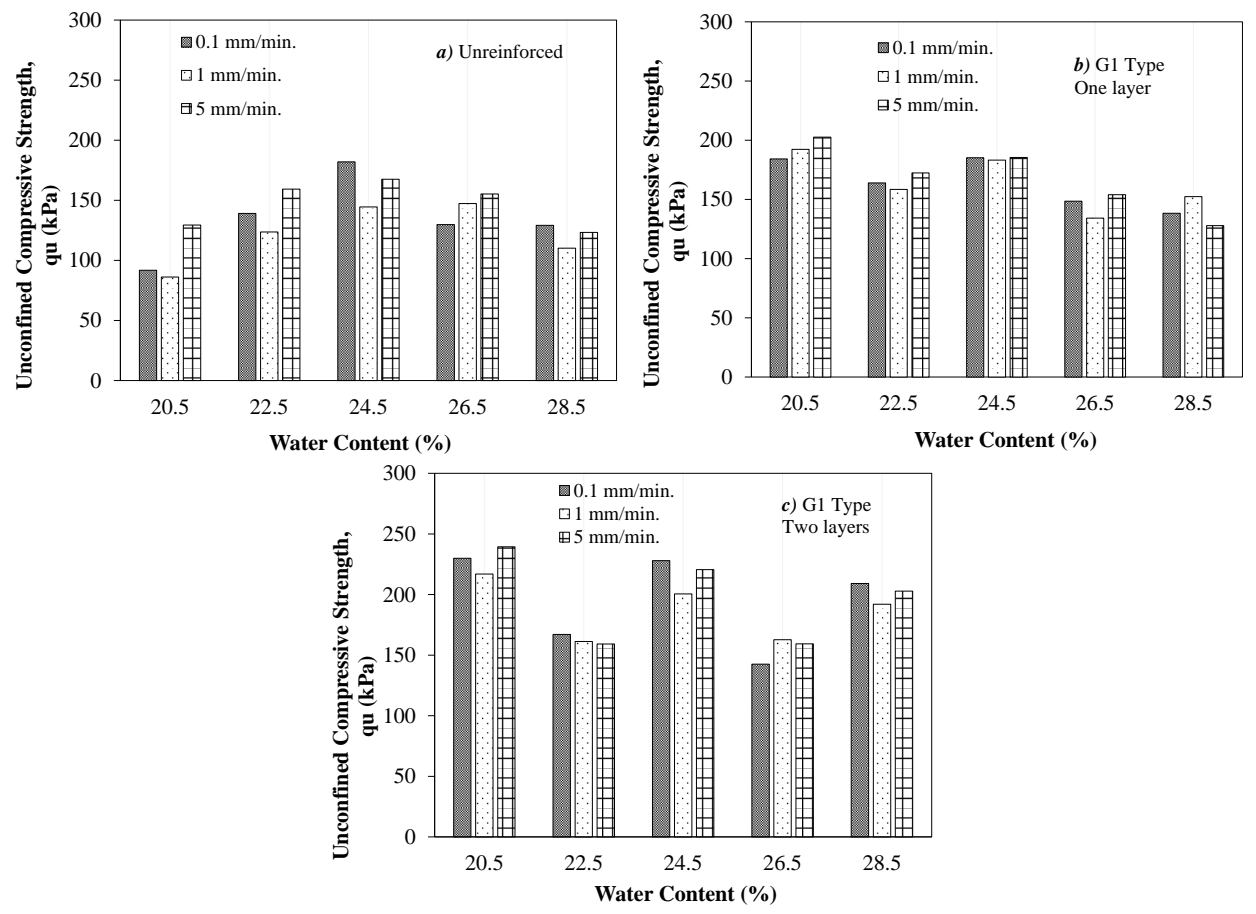

Figure 11: Variation of unconfined compressive strength based on water content for G1 type geotextile for different numbers of geotextile layers. 
E. Karakan. / Mechanical Behavior of Clay Soils Reinforced with Geosynthetics

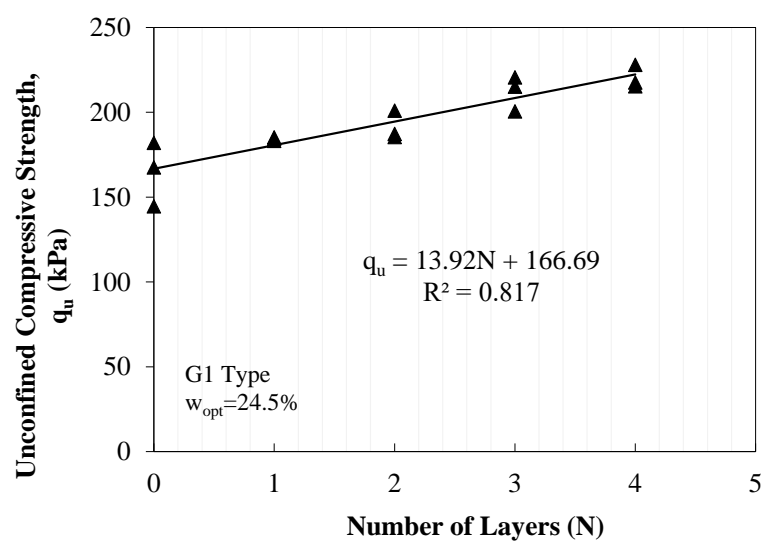

Figure 12: Variation of unconfined compressive strength based on optimum water content for G1 type geotextile for different numbers of geotextile layers.

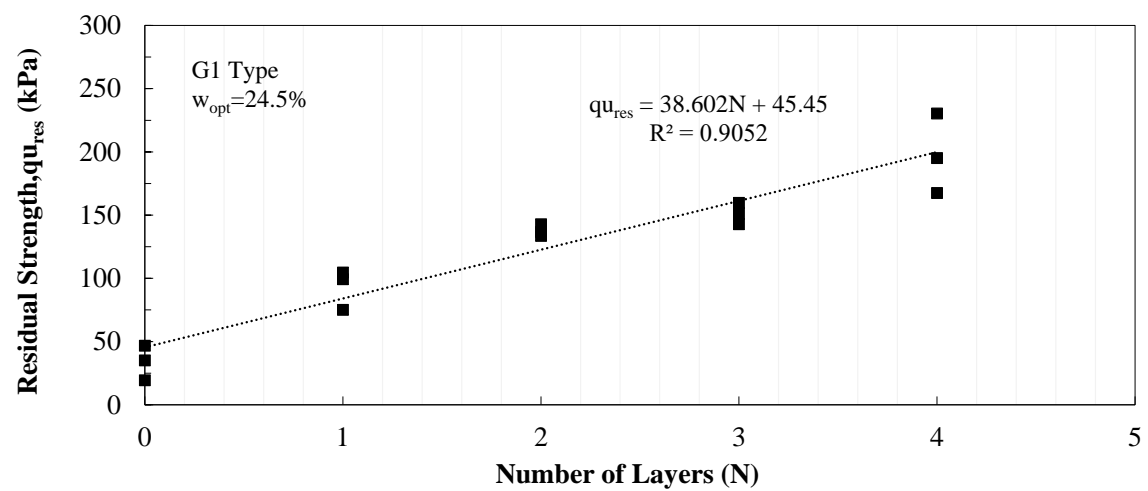

Figure 13: Relationship between residual strength and number of layers

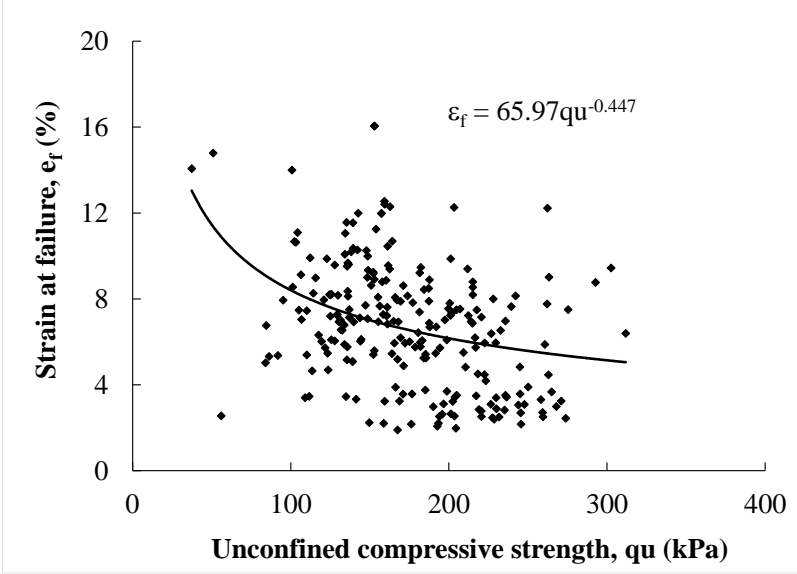

Figure 14: Relationship between strain at failure $(\varepsilon f)$ and unconfined compressive strength $(\mathrm{qu})$. 
E. Karakan. / Mechanical Behavior of Clay Soils Reinforced with Geosynthetics

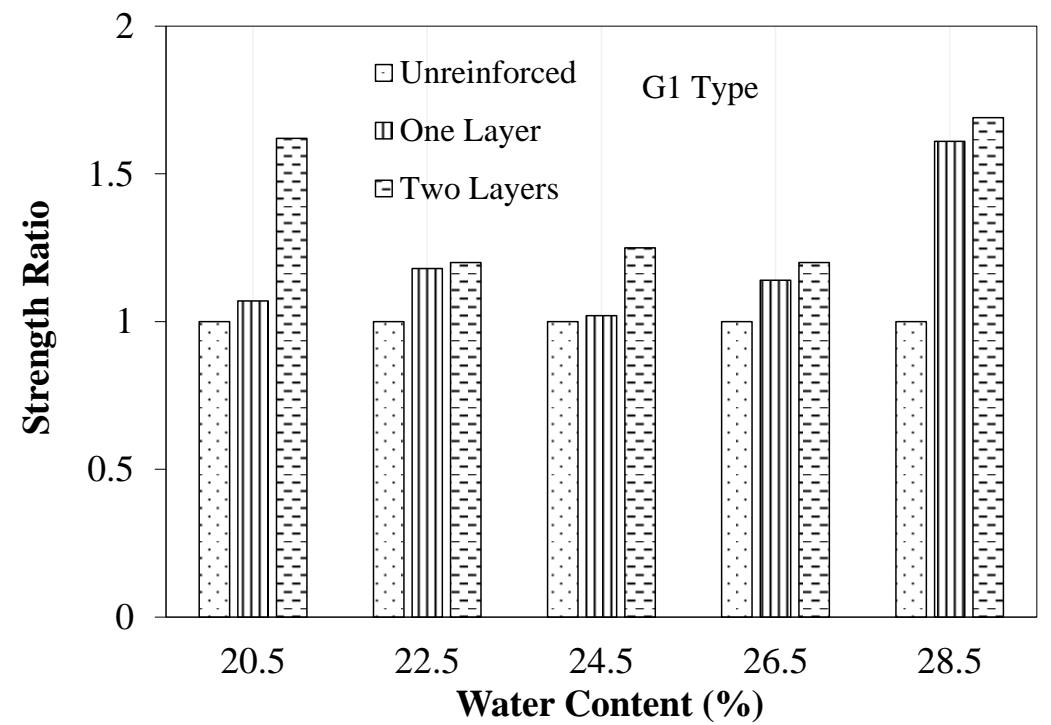

Figure 15: Variation of strength ratio with water content for G1 type geotextile for different

numbers

of geotextile

layers. 


\section{References}

[1] Long, P.V., Bergado, D.T., AbuelNaga, H.M., 2007. Geosynthetics reinforcement application for tsunami reconstruction: evaluation of interface parameters with silty sand and weathered clay. Geotextiles and Geomembranes 25 (4-5), $311-$ 323.DOI:10.1016/j.geotexmem.200 7.02.007.

[2] Ingold, T.S., 1979. Reinforced clay a preliminary study using the triaxial apparatus Argile Armee Etude Preliminaire a L'appareil triaxial. Ground Engineering, 5964.

[3] Ingold, T.S., Miller, K.S., 1983. Drained axi-symmetirc loading of reinforced clay. Journal of Geotechnical Engineering Division, ASCE 109 (7), 883-898.

[4] Lafleur, J., Sall, M., Ducharme, A., 1987. Frictional characteristics of geotextiles with compacted lateritic gravels and clays. Proceedings of Geosynthetics 87 (1), 205-215.

[5] Al-Omari, R.R., Al-Dobaissi, H.H., Nazhat, Y.N., Al-Wadood, B.A., 1989. Shear strength of geomesh reinforced clay. Geotextiles and Geomembranes 8 (4), 325-336.

[6] Indraratna, B., Satkunaseelan, K.S., Rasul, M.G., 1991. Laboratory properties of a soft marine clay reinforced with woven and nonwoven geotextiles. Geotechnical Testing Journal, ASTM 14 (3), 288-295.

[7] Zornberg, J.G., Mitchell, J.K., 1994. Reinforced soil structures with poorly draining backfills, Part I.
Geosynthetics International 1 (2), 103-148.

[8] Unnikrishnan, N., Rajagopal, K., Krishnaswamy, N.R., 2002. Behavior of reinforced clay under monotonic and cyclic loading. Geotextiles and Geomembranes 20, 117-133.

[9] Noorzad, R., Mirmoradi S.H., 2010, Laboratory evaluation of the behavior of a geotextile reinforced clay, Geotextiles and Geomembranes, 28,386-392.

[10] Ghazavi, M., Roustaie, M., 2010, The influence of freze thaw cycles on the unconfined compressive strength of the fiber reinforced clay, Cold Regions Science and Technology, 61, 125-131.

[11] Maher MH, Gray DH, 1990. Static response of sand reinforced with randomly distributed fibers. Journal of Geotech Eng ASCE 116(11):1661-1677

[12] Al-Rafeai T.O., 1991. Behavior of granular soils reinforced with discrete randomly oriented inclusions. Geotext Geomembr 10:319-333

[13] Consoli NC, Vendruscolo MA, Fonini A, Dalla Rosa F 2009. Fiber reinforcement effects on sand considering a wide cementation range. Geotext Geomembr 27:196203

[14] Yetimoglu T, Salbas O 2003. A study on shear strength of sands reinforced with randomly distributed fiber. Geotext Geomembr 21:103-110

[15] Ahmad F, Bateni F, Azmi M 2010. Performance evaluation of silty 
sand reinforced with fibers. Geotext Geomembr 28:93-99

[16] Maher MH, Ho YC, 1994. Mechanical properties of kaolinite/fiber soil composition. J Geotech Eng ASCE 120(8):13811393

[17] Consoli NC, Montardo JP, Prietto PDM, Pasa GS 2002. Engineering behavior of a sand reinforced with plastic waste. J Geotech Geoenviron Eng ASCE 128(6):462-472

[18] Mesbah A, Morel JC, Walker P, Ghavami Kh 2004. Development of a direct tensile test for compacted earth blocks reinforced with natural fibers. J Mater Civil Eng ASCE 16:95-98

[19] Kumar A, Walia BS, Bajaj A 2006. Compressive strength of fiber reinforced highly compressible clay. J Constr Build Mater 20:10631068

[20] Tang C, Shi B, Gao W, Chen F, Cai, Y 2007. Strength and mechanical behavior of short polypropylenefiber reinforced and cement stabilized clayey soil. Geotext Geomembr 25:194-202

[21] Attom MF, Al-Akhras N M, Malkawi AIH 2009. Effect of fibers on the mechanical properties of clayey soil. In: Proceedings of the institute of civil engineers, geotechnical engineering, vol 162(GES), 277-282

[22] ASTM D2166 / D2166M - 13 Standard Test Method for Unconfined Compressive Strength of Cohesive Soil

[23] Tang GX, Graham J. A method for testing tensile strength in unsaturated soils. Geotechnical
Testing Journal 2000; 23 (3) : 377 e 81.

[24] R. Noorzad, S.H. Mirmoradi , 2010. Laboratory evaluation of the behavior of a geotextile reinforced clay, Geotextiles and Geomembranes 28 (2010) 386392.DOI : 10. $1016 /$ j. geo tex mem. 2009. 12.002

[25] Fabian, K.J., Fourie, A.B., 1986. Performance of geotextile reinforced clay samples in undrained triaxial test. Geotextiles and Geomembranes 4 (1), 53

[26] ASTM D422-63(2007)e2 Standard Test Method for Particle-Size Analysis of Soils 